\title{
The Universality of Mutual Respect and Humility in the Al- Quran: Towards the Construction of a Value-Based Arabic Grammar
}

Muhammad Zahid Ismail, Mohd Nizwan Musling, Mohd Rosmizi Abd Rahman

To Link this Article: http://dx.doi.org/10.6007/IJARBSS/v12-i1/12351

DOI:10.6007/IJARBSS/v12-i1/12351

Received: 17 November 2021, Revised: 19 December 2021, Accepted: 05 January 2022

Published Online: 27 January 2022

In-Text Citation: (Ismail et al., 2022)

To Cite this Article: Ismail, M. Z., Musling, M. N., \& Rahman, M. R. A. (2022). The Universality of Mutual Respect and Humility in the Al-Quran: Towards the Construction of a Value-Based Arabic Grammar. International Journal of Academic Research in Business and Social Sciences, 12(1), 2718-2736.

Copyright: @ 2022 The Author(s)

Published by Human Resource Management Academic Research Society (www.hrmars.com) This article is published under the Creative Commons Attribution (CC BY 4.0) license. Anyone may reproduce, distribute, translate and create derivative works of this article (for both commercial and non0-commercial purposes), subject to full attribution to the original publication and authors. The full terms of this license may be seen at: http://creativecommons.org/licences/by/4.0/legalcode

Vol. 12, No. 1, 2022, Pg. $2718-2736$

Full Terms \& Conditions of access and use can be found at http://hrmars.com/index.php/pages/detail/publication-ethics 


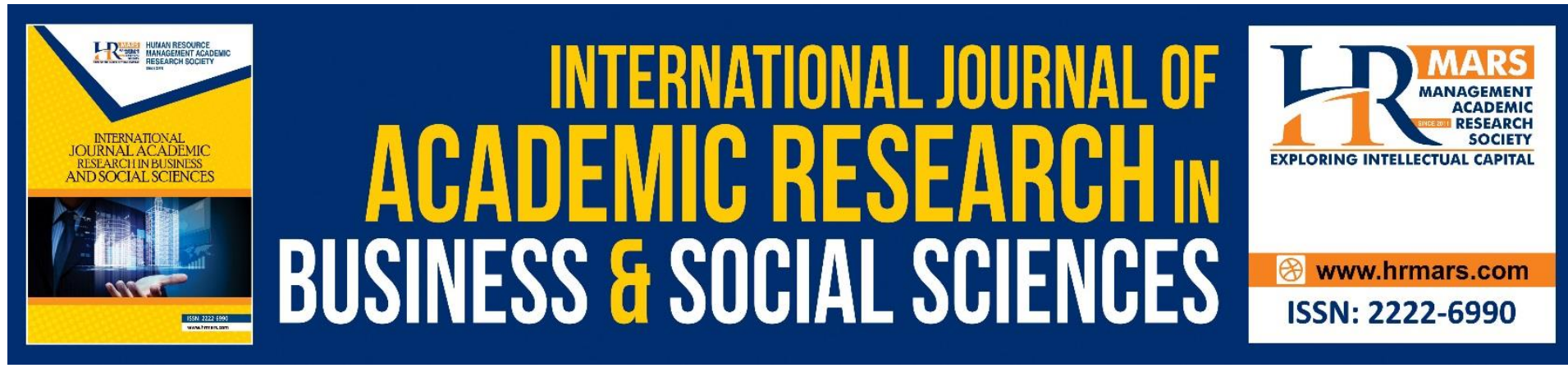

\title{
The Universality of Mutual Respect and Humility in the Al-Quran: Towards the Construction of a Value-Based Arabic Grammar
}

\author{
Muhammad Zahid Ismail \\ Islamic Science Institute, Universiti Sains Islam Malaysia, Negeri Sembilan
}

Mohd Nizwan Musling

Faculty of Major Language Studies, Universiti Sains Islam Malaysia, Negeri Sembilan

Email: mohdnizwan@usim.edu.my (corresponding author)

Mohd Rosmizi Abd Rahman

Faculty of Leadership and Management, Universiti Sains Islam Malaysia, Negeri Sembilan

\begin{abstract}
The formation of Universal Social Moral Values (USMV) is considered as one of the backbone of the Malaysian education curriculum to create harmonious individuals living in the society regardless of religion, race and belief. Nevertheless, the inculcation of these social moral values is not clearly seen in the Arabic grammar curriculum even though the main source for the curriculum comes from the al-Quran, which is loaded with values. On that account, this research analyses verses of the al-Quran containing USMV. At the same time, this research attempts to prove the universality of these values, the matching of community values according to the major religions in Malaysia such as Christianity, Hinduism and Buddhism. To achieve these objectives, a qualitative approach through content analysis is used to describe the USMV that takes place deductively and inductively in the al-Quran. The findings of the study reveal that Mutual Respect and Humility are two universal social moral values in the Malaysian context that may be used as curriculum material for Arabic-Quranic Grammar in the framework of value-based education.
\end{abstract}

Keywords: Universal Social Moral Values, Arabic Grammar, Al-Quran, Value-based Education

\section{Introduction}

One of the Sustainable Development Goals (SDG) outlined by the United Nations (UN) is to provide every individual with access to quality education. This effort aims to help members of a community attain an education in whatever situation (Ferguson et al., 2020). In line with this goal, the application of USMV (Universal Social Moral Values) is very relevant, as the foundation of the National Education Philosophy, to produce citizens who have good, balanced and holistic personalities in terms of their intellect, spirituality and physicality (Mohamed et al., 2011). This was emphasised in UNESCO's Four Pillars of Education for the 
21st Century (PAK21) namely, learning to be and learning to live together, as well as learning to know and learning to do (Zubaidah, 2016). Therefore, USMV based education needs to be inculcated from early childhood education until tertiary education to enhance the noble behaviour of students because they are the future leaders who will drive the progress and development of the country (Rashid, 2001).

Based on the study by Musling et al (2020), USMV is very closely linked to the 3rd cluster in the Universal Moral Values framework that includes the institutions of family, neighbours, friends, community and society. These institutions may consist of two or more people interacting and getting to know one another based on values of Mutual Respect and Humility. Mutual Respect is the attitude where one shows his/her appreciation and honour to a person by treating he or she well (Kertas Kerja Kajian Sistem Pendidikan Kebangsaan). While, Humility is the attitude associated with patience and not being arrogant towards others (Octavia et al., 2014).

In this regard, the Arabic Language Curriculum or Bahasa Arab (BA) in Malaysia needs to implement these two components, namely Mutual Respect and Humility, as the key of USMV in the education system for the success of the National Education Philosophy. This is because currently Arabic Language texts used in primary and secondary schools as well as in universities place little emphasis on USMV even though the Arabic Language, being synonymous with the language of the al-Quran, is loaded with values. The Arabic Language texts also rely on examples of made-up sentences because the objective of this subject is only for language acquisition. There are various recommendations with regards to the importance of inculcating values into Arabic Language learning as it can increase the awareness for these moral values, in addition to mastering such skills as listening, speaking, reading and writing (Mohamad et al., 2017). Moreover, the teaching and learning of the Arabic Language through shahid (language source text) al-Quran is very helpful to students (Rajab et al., 2015) especially for tahfiz students, in the matter of speeding up their learning process for pronunciation, reading and understanding the meaning of the words in the al-Quran, and at the same time instilling USMV.

Based on this issue, the aspect of Mutual Respect and Humility contained in the al-Quran will be extracted by applying this model as a method for teaching Arabic grammar to explore the explicit and implicit meanings behind its use in grammar. This study will identify and analyse the shahid grammar of the al-Quran that carry messages of USMV. A qualitative approach is implemented by choosing content analysis to analyse the USMV contained in the al-Quran deductively and inductively. The findings of this study will prove that these values may be applied through shahid al-Quran in Arabic grammar while improving the curriculum of Arabic Grammar education based on universal values for various racial and religious groups.

\section{Literature Review}

The formulation of Arabic grammar is seen to be based on Arabic expressions especially from Arabic poetry, thus provoking criticism from some scholars and researchers. As a result, in the 21st Century, the theory of grammar in the al-Quran was forwarded that stated the alQuran as the main medium and reference for the formulation of Arabic grammar (Al-Ansari, 1985). This theory attracted many Arab scholars who came forward to present teaching and learning materials drawn out from the al-Quran. For example, Ibnu Hisham $(1985 ; 1997)$ used 
a lot of al-Quran verses to explain Arabic grammar in his works of grammar. Using the alQuran as a reference indirectly indicates the special position of the al-Quran as a holy book that can be the foundation for the teaching and learning of Arabic grammar through the exploration of its contents. This coincides with the fact that the al-Quran should be used as the main source of reference to check and examine the accuracy of a sentence structure in an Arabic expression because there is no other sentence structure in the Arabic language that is more precise than the arrangement of the verses in the al-Quran.

However, this study will not only focus on the Arabic grammar of the al-Quran but will also emphasize its use as the language curriculum content to inculcate USMV (Musling et al., 2022). Musling et al (2020) in his study through the syntactic and semantic analysis of some Quranic verses using the framework of universal values (Kinnier et al., 2000) identified the values which were then categorised into clusters. 86 components were identified under the four main clusters which are: 1 ) the commitment to comply to a higher entity than oneself consisting of five components, 2) a virtuous personality by maintaining self-respect, discipline and responsibility consisting of 18 values, 3) respect and love for other people consisting of 33 values, and 4) caring for the environment and living things in nature has two values. However, this study will only focus on the USMV that are closely related to the 3rd cluster especially the value of mutual respect and humility. So, this study will expand what have been done by Musling et al., (2021) in their study entitled Universal Social Moral Values in Shāhid of Quranic Syntax: Nominal and Verbal Sentences.

The importance of instilling USMV may be seen through various viewpoints. Umar (2017) emphasised that social values are invaluable for fostering relationships between humans in building their personalities as a whole and to broaden students' identities mentally, socially and morally. In addition, social values such as cooperation and helping each other are needed in education to develop individuals with leadership qualities and honourable personalities. Similarly, the study done by Jomaa (2018) stated that social values, when applied into the Arabic language curriculum, guid students to maintain good student-teacher relations in terms of their speech and behaviour. The methodology used to instil these social moral values in them was through utilising poems, poetry and verses that contain messages of honesty, unity, brotherhood and so on.

Meanwhile, the study on social values in the al-Quran conducted by Al-Ajiz \& Asaf, (2008) identified 14 social values that are contained in the al-Quran namely, loyalty, honesty, mutual respect, doing good deeds and avoiding wrongdoings, forgiving, being humble, making peace, being fair, being gentle, spreading the greeting of salam, tightening relationships, kindheartedness, being honourable, taking care of relationships with the community and truthfulness. This study aims to look at educational reflections on social values towards students of the Islamic University of Gaza. Hence, the questionnaire method was chosen to survey the differences in the effects among students who were given lessons instilled with social values. The findings found that using al-Quran verses with messages of social values has reflected positively on the morals of the students interacting with members of their surrounding community.

Based on past studies, it may be deduced that using texts or shahid al-Quran in the teaching of the Arabic language to instil USMV has not been explored yet especially with regard to the 
values of Mutual Respect and Humility. Therefore, this study attempts to expand further the study of shahid al-Quran by exploring the explicit and implicit meanings behind the USMV messages. This was recommended by Rajab et. al., (2016) who stated that the al-Quran is loaded with moral values. To prove that there are USMV in the al-Quran, this study will analyse, according to Arabic syntax, Quranic verses for as long as it contains USMV messages, that are also advocated, in principle, by other religions. Then, this study will try to fill out the gaps and fulfil the needs following the government's aspirations through the National Education Philosophy that emphasize value-based education.

\section{Methodology}

This study uses a qualitative approach that aims to collect data in the form of words or texts, explaining and analysing according to themes (Merriam et al., 2016). The main source of the study is the al-Quran text, while the secondary sources are the tafsirs of the al-Quran, books, articles, journals and other related documents in print or online (Saldana, 2011). Furthermore, this study uses six-phase method to analyse the data as shown in the table below:

\begin{tabular}{|c|c|c|c|}
\hline & Phase & Description of the process & Application and Adaptation \\
\hline 1. & $\begin{array}{l}\text { Familiarizing } \\
\text { yourself with } \\
\text { your data }\end{array}$ & $\begin{array}{l}\text { Transcribing data (if } \\
\text { necessary), reading and re- } \\
\text { reading the data, noting } \\
\text { down initial ideas }\end{array}$ & $\begin{array}{l}\text { Analyze the universal ethical value } \\
\text { framework demonstrated by } \\
\text { Musling et al., (2020) and will } \\
\text { match it with Arabic grammar }\end{array}$ \\
\hline 2. & $\begin{array}{l}\text { Generating initial } \\
\text { codes }\end{array}$ & $\begin{array}{l}\text { Coding interesting features of } \\
\text { the data in a systematic } \\
\text { fashion across the entire data } \\
\text { set, collating data relevant to } \\
\text { each code. }\end{array}$ & $\begin{array}{l}\text { This study will identify the verses } \\
\text { of the Qur'an inductively and } \\
\text { deductively. This process will look } \\
\text { at the characteristics of verses or } \\
\text { surahs makkiyyah and madaniyyah } \\
\text { to produce values that are } \\
\text { universal in terms of concepts and } \\
\text { components }\end{array}$ \\
\hline 3. & $\begin{array}{l}\text { Searching } \\
\text { themes }\end{array}$ & $\begin{array}{l}\text { Collating codes into potential } \\
\text { themes, gathering all data } \\
\text { relevant to each potential } \\
\text { theme }\end{array}$ & $\begin{array}{l}\text { Based on the universal value } \\
\text { framework of Musling et al., } \\
\text { (2020), the study will focus on the } \\
\text { 3rd cluster that has relationships } \\
\text { with others. }\end{array}$ \\
\hline 4 & $\begin{array}{l}\text { Reviewing } \\
\text { themes }\end{array}$ & $\begin{array}{l}\text { Analyze related themes and } \\
\text { extract data based on the } \\
\text { objectives of the study }\end{array}$ & $\begin{array}{l}\text { This process will extract the } \\
\text { features and values found in } \\
\text { cluster-3. Then prove its } \\
\text { universality by linking those values } \\
\text { with the common beliefs } \\
\text { contained in other religions such as } \\
\text { Christianity, Hinduism and } \\
\text { Buddhism. }\end{array}$ \\
\hline 5. & $\begin{array}{l}\text { Defining and } \\
\text { naming themes }\end{array}$ & $\begin{array}{l}\text { Ongoing analysis to refine the } \\
\text { specifics of each theme, and } \\
\text { the overall story the analysis } \\
\text { tells, generating clear }\end{array}$ & $\begin{array}{l}\text { The values that have been } \\
\text { extracted from the Quran, will then } \\
\text { be matched to the appropriate } \\
\text { Arabic grammar chapters. This } \\
\text { process is also done in reverse }\end{array}$ \\
\hline
\end{tabular}




\begin{tabular}{|c|c|c|c|}
\hline & & $\begin{array}{l}\text { definitions and names for } \\
\text { each theme }\end{array}$ & $\begin{array}{l}\text { (Arabic Grammar to Ethical } \\
\text { Values). }\end{array}$ \\
\hline 6. & $\begin{array}{l}\text { Producing the } \\
\text { report }\end{array}$ & $\begin{array}{l}\text { The final opportunity for } \\
\text { analysis. Selection of vivid, } \\
\text { compelling extract examples, } \\
\text { the final analysis of selected } \\
\text { extracts, relating back of the } \\
\text { analysis to the research } \\
\text { question and literature, } \\
\text { producing a scholarly report } \\
\text { of the analysis }\end{array}$ & $\begin{array}{l}\text { The ethical values of cluster-3 or } \\
\text { the Universal Social Ethical Values } \\
\text { that have been matched in Arabic } \\
\text { grammar will be proven to be } \\
\text { capable of being used as Arabic- } \\
\text { Quranic grammar curriculum } \\
\text { material in a value-based } \\
\text { educational framework }\end{array}$ \\
\hline
\end{tabular}

Table 1. Phases of Data Analysis (Braun \& Clarke, 2006)

Based on the phases above, the method of data collection based on the al-Quran text 'riwayat Hafz' from Imam al-A'sim will be analysed deductively and inductively.

Deductive Approach: Deductive reasoning works from the more general to the more specific. Sometimes this is informally called a "top-down" approach Conclusion follows logically from the facts (Creswell \& Poth, 2017).

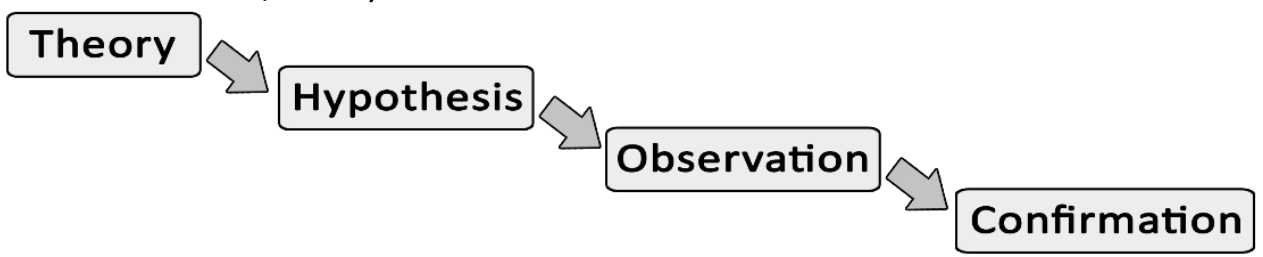

The Makkiyyah surah was the surah revealed by Allah through Jibril AS before the Prophet s.a.w. migrated from Mecca to Medina. The Makkiyyah surahs are characterised by information that deals with subjects that are universal or general in nature. Hence, this study will identify the verses that carry USMV messages using the characteristics of the ayats or Makkiyyah surah. The phrase, "يا أيها الناس", which means " "O people," is often used in most Makkiyyah surah (Al-Sayuti, 1974).

Inductive Approach: Inductive reasoning works the other way, moving from specific observations to broader generalizations and theories. Informally, this is sometimes called the "bottom-up" approach. The conclusion is likely based on a degree of uncertainty (Creswell \& Poth, 2017).

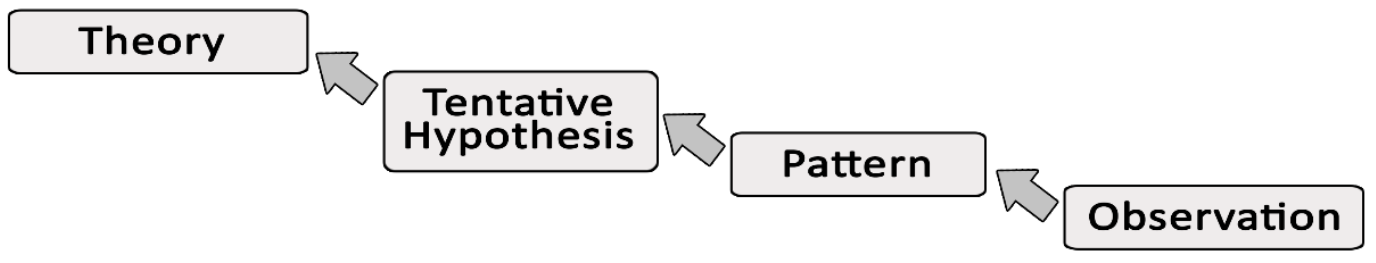

The Madaniyyah surah was revealed by Allah through Jibril AS to Prophet Muhammad s.a.w. throughout his stay in Medina. These surahs are characterised by the information that they contain messages that are specifically for Mukmins (believers). The phrase, "يا أيها الذين آمنوا", which means "O you who believe," is used to refer to Muslims who are devoted to Allah and Prophet Muhammad s.a.w. (Al-Sayuti,1974). Even though most Madaniyyah surahs are intended specifically for believing Muslims, however the Madaniyyah surahs also use the phrase, "يا أيها الناس", such as in al-Baqarah surah, verse 21st (Nirwana, 2008). Therefore, this 
study will examine the entire verse of the al-Quran which cover both Makkiyyah and Madaniyyah surah.

At the data analysis stage, this study will focus on the 3rd cluster of the Universal Moral Values framework by Musling et al., (2020) which is ethical values in social relationships with others. The features contained in the third cluster will then be matched with secondary sources i.e. statements about the existence of USMV (Mutual Respect and Humility) in other religions such as Christianity, Hinduism and Buddhism. This would prove the universality of these values as the values are also practised by other religions besides Islam.

Next, the USMV (Mutual Respect and Humility) from the al-Quran in tandem with statements from each of the other religions mentioned will be matched with the relevant Arabic grammar topics. This analysis was made based on the tafsirs of the al-Quran and related Arabic grammar books.

\section{Concept Structure}

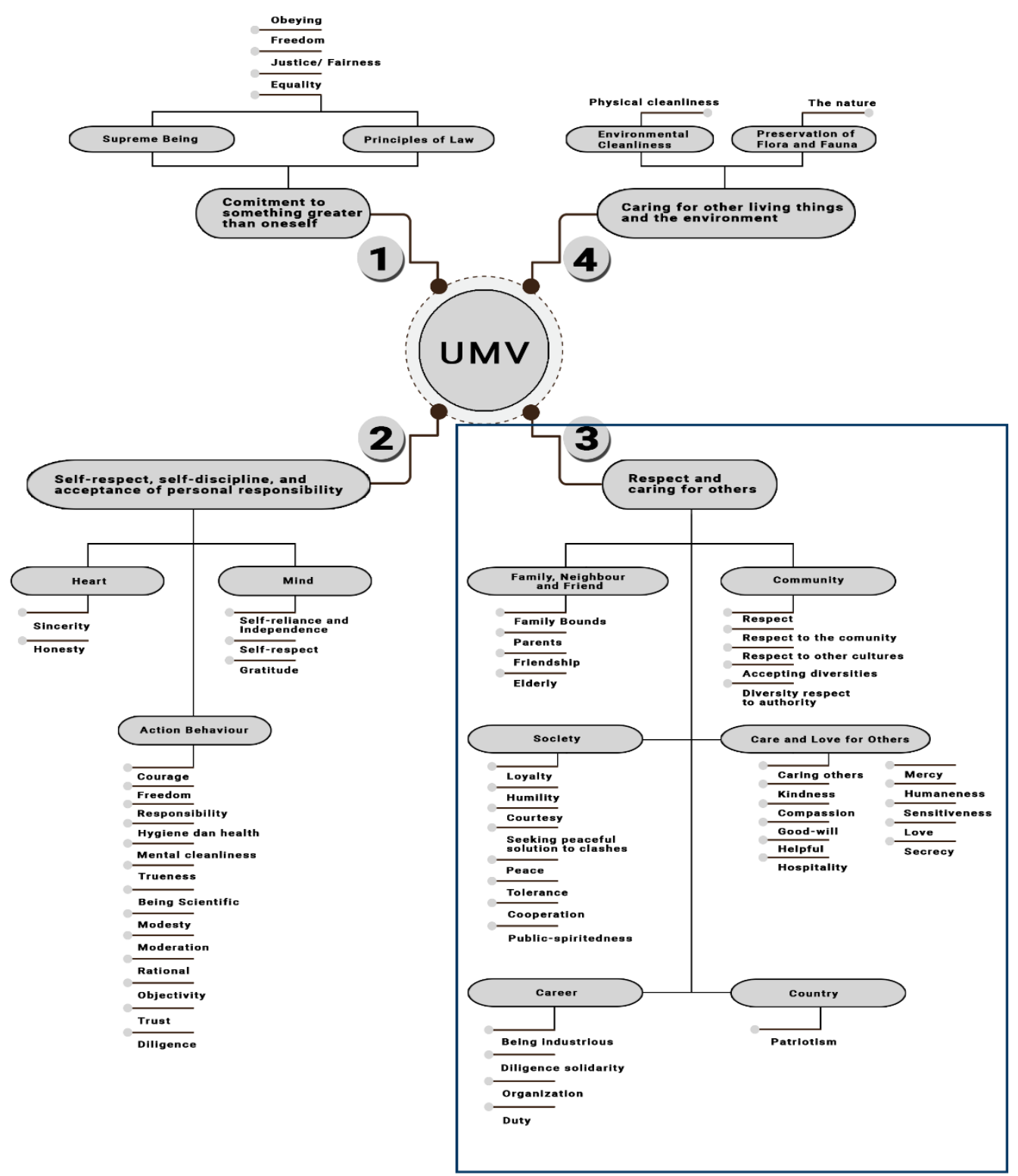

Diagram 2: Clusters and Components of Universal Moral Values (Musling et al., 2020). 
As shown in the diagram above, the 3rd cluster consisting of, 1) Family, Neighbours and Friends, 2) Society, 3) Community, 4) Loving and Caring for other people, 5) Career and 6) Country is a social entity that has the same meaning with the concept of maintaining good and close relationships between individuals to other individuals either on the level of family, community, society, career or country (Musling et al., 2020; Elvina, 2017; Al-Qadhi et al., 2012). On that account, it is evident that the values in the 3rd cluster are closely related to USMV because it involves social relationships and good behaviour among human beings. Among the components of the universal social values in the 3rd cluster, categorised into 5 parts according to the level of the social entity are:

\section{Part 1: Social values toward the Community}

A community consists of small groups of society that are situated in a particular area. It refers to the sharing of social values of people from units as small as a village to ones as large as a country (Abdullah et al., 2017).

1) Respect - appreciate and honour a person by treating them well (Zbar et al., 2003; Kertas Kerja Kajian Sistem Pendidikan Kebangsaan).

2) Respect for the Community - Respecting a multi-racial and multi-religious community irrespective of colour, appearance and background (Keown et al., 2005).

3) Respect for other cultures - Respecting the diversity of beliefs and customs from various cultures and ethnicities (Haydon, 2006).

4) Accepting diversity - Accepting people of different cultures, ethnic backgrounds, races and religions (Keown et al., 2005).

Respecting leaders who are in power - Showing respect, compliance and loyalty to leaders or authorities (Cicek et al., 2012).

\section{Part 2: Social values toward Society}

A society is a mass of people living in a particular group consisting of other humans who share a common culture and set of rules. In general, society consists of various races ( ethnic groups or tribes) (Abdullah et al., 2017).

1) Loyalty - feelings of affection, willingness to make sacrifices, protecting and defending something that is loved and cherished concerning relationships with others (Sinar Harian, 2018).

2)Humility - This attitude is related to patience and not being arrogant. It is the attitude of people who are aware of the limitations of their abilities and, as a consequence, they do not feel arrogant or proud towards others (Octavia et al., 2014).

3) Well mannered - Speaking using polite and respectful words (Musa et al., 2012; Osman \& Wahab, 2018).

4) Seeking a peaceful solution to hostility - Always seeking peace or tranquillity by prioritising peace in the event of a conflict (Yaakob \& Moris, 2019).

5) Peace - Harmony between different social groups that are characterised by no violence or conflicts, and are free from fears of violence (Yaakob \& Moris, 2019).

6) Tolerance - Openness, compromise, patience and forgiving are attitudes that would prevent a person from starting arguments that would result in conflicts and misunderstandings with others (Engelen \& Nys, 2008). 
Cooperation - Efforts made by several individuals or groups to attain a common goal (Khamis et al., 2006).

Community spirit - the tendency to work together for the common good to create harmony in society (Kertas Kerja Kajian Sistem Pendidikan Kebangsaan).

\section{Part 3: The social values of Caring and Loving others}

1) Consideration towards others - The concepts of caring, attentiveness and concern for others are reflected through one's actions towards others (Como, 2007).

2) Affection - A deep everlasting love that developed without force. It is born from the heart that is willing to do something without any element of self-interest (Caldwell, 2017; Kertas Kerja Kajian Sistem Pendidikan Kebangsaan).

3) Sympathy - Feelings of understanding the suffering or sorrow of others which motivates a person to act by giving a helping hand (Strauss et al., 2016)

4) Kind-hearted - The attitude of always caring for the feelings and welfare of others, sincerely (Kertas Kerja Kajian Sistem Pendidikan Kebangsaan).

5) Helpful - The desire and the willingness to help other people (Merey et al., 2012).

6) Hospitality - Honouring Guests and others by welcoming them with courtesy (Omar \& Mohamed, 2014).

7) Give forgiveness - Feelings of pity for others (Extraordinary Jubilee of Mercy).

8) Humanity - Actions based on rational thinking, consideration and love for others (Eileen et al., 1975).

9) Sensitivity - The positive emotional and physical feeling that exists within a person as a response to what is happening around them (Kafadar et al., 2018).

10) Love - A deep sense of interest for others and a willingness to sacrifice for them without any element of personal interest (Treger et al., 2013).

11) Keeping secrets - The trait of individuals who maintain confidentiality without causing embarrassment to others (Bradley, 2013).

\section{Part 4: Social values toward Careers}

Careers are activities and positions that involve jobs and tasks as well as having relationships throughout the individual's life (Zunker, 2006).

1) Being industrious - A person who understands the importance of working and desires to work without any coercion (Taku, 1996).

2) Diligence solidarity - A person who works diligently in an organisation (Taku, 1996; Katilmis, 2017).

3) Organisation - The concept of cooperating with each other in a company or organisation to achieve common objectives (Taku, 1996).

4) Tasks - Understanding one's duties and responsibilities, in a company or organization, which need to be executed properly (Godlewski, 2015).

\section{Part 5: Social values towards the Country}

A country is a region on the face of the earth that has its own legal system as well as an administration governed by state leaders either politically, militarily, economically, socially or culturally (Hashim \& Azhar, 2010). 
1) Patriotism - Courage, unwillingness to yield and a willingness to sacrifice for the sake of the nation and country (Gill et al., 2015).

These five parts often become the driving force of the wider community in determining their attitudes in daily life and has become the values of life used in interactions with other human beings. USMV is not inborn and is acquired only when it is used in daily life. For example, values such as respecting your neighbours may be instilled during social interactions between members of a community and so on. It may also be shaped through the learning process (socialisation) such as valuing your friendships while at school, and respecting your parents while at home. Family, neighbours, relations, surrounding communities are institutions that cultivate social values to monitor and direct all the actions of an individual (Al-Ajiz \& Asaf, 2008; Mahadi \& Sino, 2007; Rahman et al., 2016).

\section{Result and Discussion}

Based on the conceptual framework above (Diagram 2), the USMV in cluster 3 are analysed (Musling et al., 2020) These values relate to social interactions between two people i.e. an individual with another individual on either the family, community or society level. Given this fact, the study will view USMV in shahid al-Quran grammar. Hence, this study will extract alQuran verses that carry USMV messages as shown in the table below.

\begin{tabular}{|l|l|l|} 
Nos & Universal Social Values & Surah \\
\hline 1 & \multirow{2}{*}{$\begin{array}{l}\text { Mutual Respect } \\
\text { (Al-An'am 6:151) (Maryam 19:14) (Al-Ankabut 29:8) } \\
\text { (Luqman 31:14) (An-Nisa 4:36, 86) (Al-Hujurat } \\
49: 11,13)\end{array}$} \\
\hline 2 & Humility & (Al-Furqan 25:63) (Luqman 31: 18) (Luqman 31:19)
\end{tabular}

\section{Table 3. The Distribution of USMV contained in the al-Quran}

\section{Mutual Respect}

This value carries the meaning of concepts such as appreciating, honouring parents, relatives, orphans, the poor, neighbours, friends, travellers and respecting our community irrespective of culture, race and religion. These values may be observed through services given, respecting or treating someone with kindness (Musling et al., 2020). Among the ayats that explain the concept of value are al-An'am (6:151), Maryam (19:14), al-Ankabut (29:8), Luqman (31:14), an-Nisa 4:36, 86) dan al-Hujurat $(49: 11,13)$.

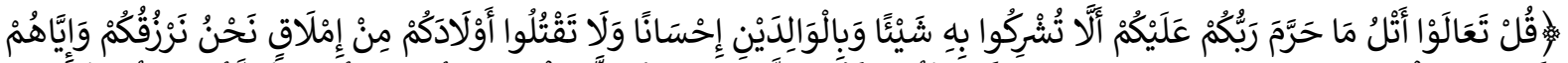

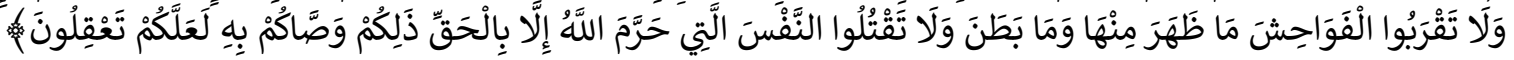
Meaning: "Say: "Come, I will recite to you what your Lord has prohibited you from that you shall not ascribe divinity in any way to anything besides Him; that (you) must show kindness to your parents; that you must not kill your children because of fear of poverty; We (in truth) provide for you and for them; and you must not go near evil and shameful deeds (like fornication) whether openly or in secret; and you must not take life which is forbidden by Allah, except for a just cause (which is allowed by the divine law). Thus, Allah exhorts you, that you may use your reason". (Al-An 'am 6:151) 
Meaning: "Honouring his father and mother, and neither arrogant nor rebellious". (19:14)

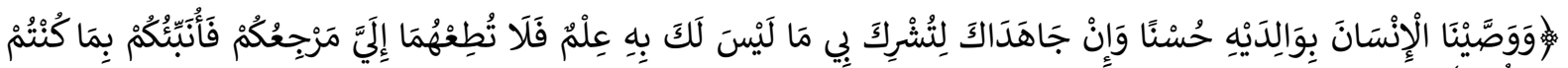

Meaning: "And We have enjoined man to show kindness to his parents. But if they bid you to ascribe divinity, side by side with Me (in worship) to something of which you have no knowledge, do not obey them. To Me is your return, and I shall declare to you all what you used to do". (29:8)

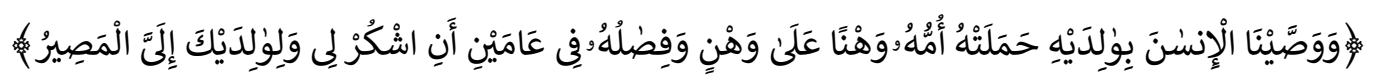

Meaning: "And We enjoined man to show kindness to his parents. His mother bore him by bearing strain upon strain (from the beginning of her pregnancy till the end of the sucking period), and his weaning is two years. Therefore, give thanks to Me and to your parents, and (remember), to Me is the final return (so that all creatures shall be rewarded)". (31:14)

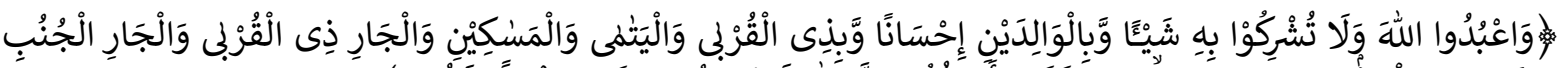

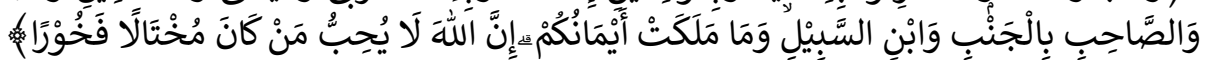

Meaning: "And serve Allah and ascribe no partners to Him. And show kindness to your parents and your kindred, to the orphans, and to the needy, to your near and distant neighbours, to companions, to the wayfarers, and to the slaves whom you rightfully possess. Allah does not love arrogant and boastful men". (4:36)

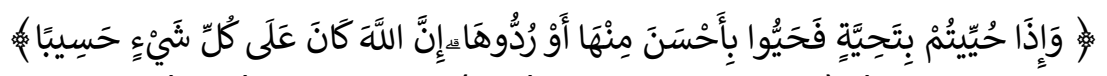

Meaning: "And when you are greeted with a greeting (such as saying peace) then answer it with a better greeting or at least return his greeting (with the same). Truly, Allah keeps count of all things". (4:86)

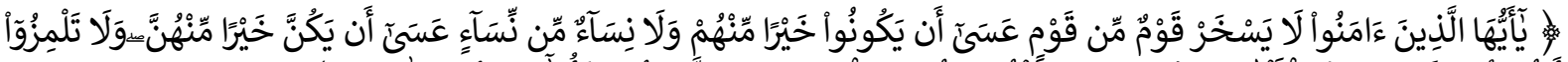

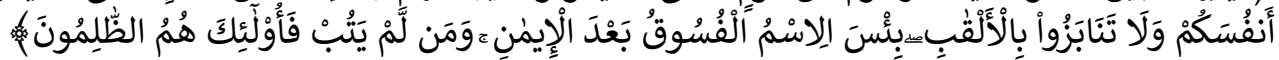

Meaning: "O believers! Let not some men among you deride others, who may perhaps be better than they. Nor let some women mock others, who may perhaps be better than they are. Do not defame one another, nor call one another by offensive nicknames. (Those who do all these will become evildoers). An evil thing indeed to be called by bad name denoting evildoing after embracing the true faith. And (remember), those who do not repent (from their evil deeds) are indeed wrongdoers". (49:11)

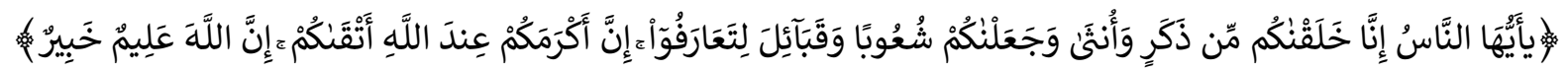
Meaning: "O Men! Truly We have created you from a male and a female and made you into nations and tribes that you might get to know (and be kind to) one another. The noblest of you in the sight of Allah is the one most deeply conscious of Him among you (not in accordance with the nobility of lineage or ethnicity). Truly, Allah is Most Knowing, Most Aware (of your state and deeds)". (49:13)

By reading through the al-Quran ayats above, it can be seen that the value of mutual respect is conveyed through five aspects of one's behaviour towards others namely being good to (parents), (relations, orphans, the poor, neighbours, friends, travellers), expressing well- 
being, not demeaning or name-calling other people, and through the aspect of getting to know one another. The value of mutual respect that involves parents can be explained in the

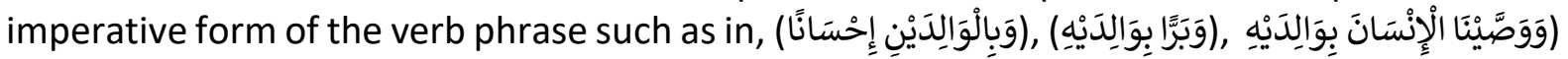

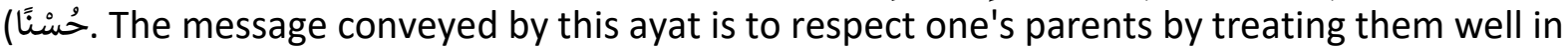
terms of the way we speak to them and our actions toward them such as obeying and carrying out their wishes so long as it does not contradict the Syara', and not being arrogant (Ibnu Kathir, 1999; at-Thabari, 1999). Hence, respect is the value that needs to be instilled in oneself from an early age so that a close relationship may be forged between children and

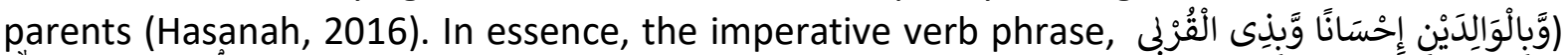

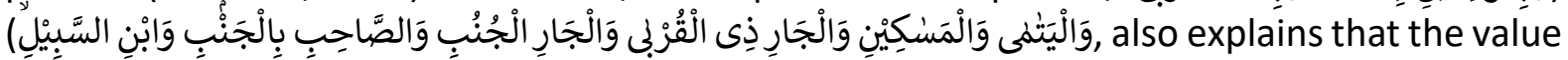
of mutual respect is not only for parents but also for relatives (to maintain ties), orphans (caring for them with love), the poor (extending assistance so that their needs are taken care of), neighbours (maintaining close relationships with neighbours both near and far) and travellers ( treating them with kindness as guests) (Ibnu Kathir, 1999; At-Thabari, 1999).

This value of mutual respect is also revealed through the imperative verb phrase, فَحَحَيُوا بأََحْسَنَ امِنْهَا أَوْ رُدُّوهَا) which is a greeting of well-being, used when greeting others, and that also functions as one's prayer for the safety of that person (Ibnu Kathir, 1999). Meanwhile, another verb phrase that conveys the message of respecting others refer to deeds that are

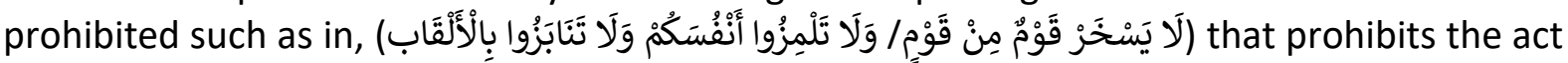
of degrading people using words, speech and actions as well as name-calling (Ibnu Kathir, 1999; Al-Maraghi, 1946). (سخر) means belittling or exposing a person's shortcomings through words and conversations. While (ولا تلمزوا) means reprehensible behaviour using words, hand

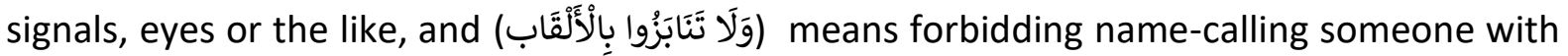
a name they dislike (Ibnu Kathir, 1999; At-Thabari, 1999). Such prohibitions are intended to ensure the good behaviour of human beings either through their words or actions, with other people (Siti Ngaisah, 2018). Next, the value of respect that can be seen in a community or society where everybody knows one another is conveyed in the declarative verb phrase,

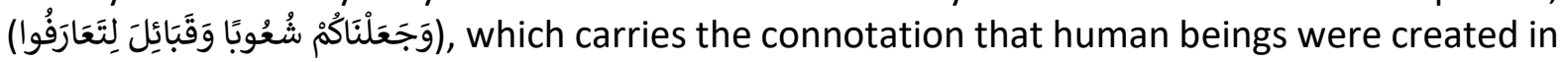
various races and tribes with the aim that they get to know each other because when there is familiarity and interaction between communities than the value of respect for one another will natural occur (Ibnu Kathir, 1999; Al-Qurtubi, 1964).

The universality of these values can be proven through the general principles of other religions such as Christianity and Hinduism. Christianity is sourced from the Bible which contains the Old Testament and the New Testament. The Ten Commandments in the Old Testament highlights ten moral values that must be observed by the Christian believer and one of them is defending the rights of one's neighbours and others (Aziz, 2004). While the values about daily life contained in The New Testament are love one's neighbours, do not insult others, and love others as you would love yourself (Aziz, 2004). Next, Hinduism, in the context of the moral principles practised, is classified into two parts which are; Yamas (moral self) and Niyamas (morals for the importance of public interest). One of the social moral values found in Niyamas is Santosha which is respecting one another (Aziz, 2004). Besides that, the value of respect as stated in Buddhism (apaciti, cittikkāra or gārava) is a feeling of awe towards the goodness and achievement of someone and expressing that feeling to the person through words and deeds. Gautama Buddha stated that the ability to respect is a great blessing to other religions, other people's property and animals (Shaharom, 2019). 
Confucianism also emphasizes the mutual respect and make it as the foundation of it Hsiao (Filial Piety) and the 5 Great Relationship. For instance, Confucianism teaches that each parties, such as father and son, the elder brother and the younger brother, husband and wife, as well as the elder and younger, should be respectful to each other. Mutual respect also can be seen in the Confucian virtues of Shu (reciprocity) in the form of the silver rule which states do not do unto others what you would not wish done to yourself. On the other hand, The Five Virtues of Confucianism states that Confucius should practice $Y i$ which means rightness and the respect of duty; one must respect his/her position as a guardian towards nature and humanity.

\section{Humility}

Humility in Arabic is (التواضع) which refers to the human nature and behaviour that openly appreciates and honours others without any feelings of arrogance (Rozak, 2017; Octavia et al., 2014). It involves two aspects of human behaviour i.e. through actions (walking humbly) and words (not raising your voice). Below are among the ayats that explain these concepts: -

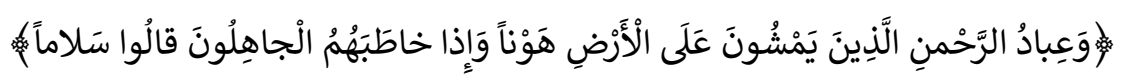

Meaning: "And the true servants of Allah the Most Gracious (who attain to His good pleasure) are those who walk humbly on the earth, and when the ignorant ones lacking in courtesy and propriety address them, they reply back in words of gentleness and propriety". (25:63)

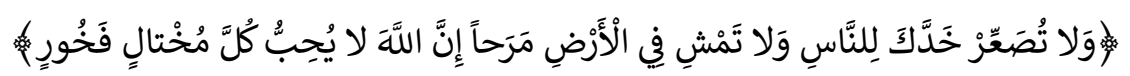

Meaning: "And do not turn your face away from people with pride (because you look down on them), nor walk proudly on the earth. Indeed, Allah does not like any arrogant boaster". $(31: 18)$

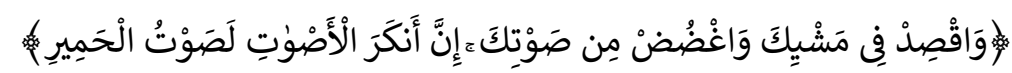

Meaning: "Rather be moderate in your pace, and lower your voice (when you talk). The ugliest of all voices is the braying of the ass". (31:19)

Based on the ayats above, humility, as described, involves two aspects of behaviour towards other people namely through actions (symbolised by the way a person walks on the face of the earth full of humility, not arrogant and not in a hurry), and words (replying to a greeting of well-being, without raising one's voice, to an ignorant who speaks arrogantly). Humility is

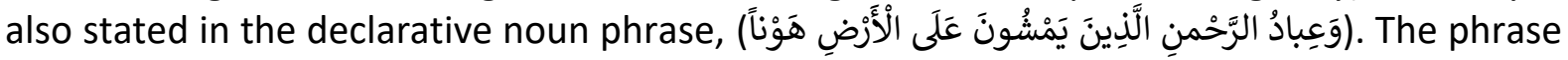
explains the traits of the servants of Allah who, while walking, will walk with humility and when the ignorant use degrading words to describe them, they will reply with a greeting of peace and forgiveness as stated in the conditional phrase, (وَاذِا خاطَبَهُمُ الْجاهِلُونَ قالُوا سَلاماً) (Ibnu Kathir, 1999). This verse describes one's trait of humility by acting humbly while walking and speaking softly to other people without being haughty (Ummah, 2017).

Humility is also mentioned in this verb phrase used to prohibit which is, (وَلا تُصَعِّر خَدََّكَ لِلنََّسِ) that relates to orders prohibiting arrogant acts (turning away) while in conversation with other people (Ibnu Kathir, 1999; Al-Qurtubi, 1964) as well as walking arrogantly وَلا تَمَشِ فَرَ) الُْأَرَضِ مَرَحاً (Ibnu Kathir, 1999). The prohibition order in the verb phrase shows the aspect of humility through one's speech and actions to other people while interacting face to face (Sutikno, 2013). In relation to that, the verb phrase used as a command in Allah's decree, also explains walking humbly by taking medium steps (refined), not walking 
too fast and not too slow and (وَاغْضُضن مِن صَوْتَكَكَ) when speaking, to not raise one's voice (use a soft and gentle voice) (Ibnu Kathir, 1999) The message implied through the verses relate to the concept of humility as a tool to maintain good human behaviour in terms of words and deeds (Nurhayati, 2017).

Humility, being a universal value, is also practised in Buddhism. Manggala Sutta describes humility as one of the thirty-eight major blessings of happiness in life. People who naturally practise humility are those who possess the ability to understand their own weaknesses in various circumstances so much so that they strive to work hard to improve themselves (HarianSIB, 2020). Buddhism is known as a religion of self-control and it encourages man to practice humility as among the way to guard themselves from evil such as pride and arrogance (Rosmizi, 2010). The Buddha considers those who are proud as an outcast. The Buddha said "Whoever is debased by his pride, exalts himself and belittles other - know him as an outcast." (Vasala Sutta, 17). In Christianity, humility is even emhapsized and it is considered as one of the importance social virtue. Saint Augustine, for instance, urges Christians to fllow the humility of Jesus. Augustine preached "Life in this world is certainly the time of our humiliation." (Sermon 206.1). At other occasion, he argues that "The humility of Christ has taught us to be humble because he yielded to the wicked in his death..." Hinduism also emphasize on controlling oneself and being humble. This is among the component of the dharma (duty or moral obligation). Thus a Hindu should always practice humility, content with his lots or caste and favour pride and arrogance. A Hindu should not feel pride or arrogance to assume other duties and neglecting his own duty. Bhagavad Gita 3:35 has reminded this issue "Your own duty done imperfectly is better than another man's done well. It is better to die in one's own duty; another man's duty is perilous." Hinduism also reminds Hindus to detach themselves from pride, world of desire, self-aggrandizement and other evils. Hinduism teaches that a Hindu should always humble, be content with his life, and free from envy (Bhagavad Gita 4.16-23)

\section{Conclusion}

The universality of Mutual Respect and Humility may be proven through verses in the alQuran and general teachings found in several religions of the world such as Hinduism, Buddhism and Christianity. The al-Quran verses may be used as the source language in the formulation of the Arabic grammar of the al-Quran. This research found that the ayats mentioned consist of declarative noun phrases and declarative, command, prohibition, and expectation verb phrases. The process is proven through the method of syntactically analysing the structure of the verses of the al-Quran which includes two components of universal social values, namely: 1) Mutual Respect, and 2) Humility. Furthermore, this language material may be placed in the Arabic-Quran grammar curriculum based on values that not only has the objective of gaining language skills or language tools but also as an agent to inculcate universal social values. This is in line with the efforts of the National Education Philosophy that desires to produce a balanced human being in terms of intellect, spirituality, physicality and emotionality. Therefore, this study suggests that the application of universal moral values through Arabic-Quranic grammar be further expanded to include other Arabic grammar topics according to the other components of Universal Moral Values, as well as study the aspects of its implementation and effectiveness. 


\section{Acknowledgement}

This paper is part of a research project supported by the Malaysian Ministry of Higher Education, under Fundamental Research Grant Scheme for Research Acculturation of Early Career (FRGS-RACER), entitled Model Baharu Kurikulum Nahu Arab-Quran Bagi Penerapan Nilai Murni Sejagat, (Research Code: RACER/1/2019/SSI01/USIM//1, and USIM/FRGSRACER/FPBU/50719).

\section{Corresponding Author}

Mohd Nizwan Musling

Faculty of Major Language Studies, Universiti Sains Islam Malaysia, Bandar Baru Nilai, 71800 Nilai, Negeri Sembilan.

Email: mohdnizwan@usim.edu.my

\section{References}

Abdullah, M., Abdullah, A. H., \& Rosman, A. S. (2015). Identifikasi peranan Ibu Bapa dalam memastikan kelangsungan pendidikan tahfiz anak-anak. Seminar Antarabangsa Isu-isu Pendidikan. Kolej Universiti Islam Antarabangsa Selangor. Retrieved May 15, from https://www.academia.edu/39721961/Murihah_Abdullah_Identifikasi_Peranan_lbu_ Bapadalam_Memastikan_Kelangsungan_Pendidikan_Tahfiz120190629_120675_3jzspf

Abdullah, M. S., Nor, M. M., Yusof, A. R., \& Husain, F. (2017). Konsep komuniti dan perkembangannya: Suatu tinjauan kritikal terhadap penggunaannya. Journal of Social Sciences and Humanities, 12(3), 1-15.

Al-Ajiz, F. A, \& Asaf, M. A. M. (2008). Implikasi pendidikan nilai sosial dalam Al-Quran mengenai pelajar Universiti Islam Gaza. 401-430. Retrieved October 20, 2020 from http://research.iugaza.edu.ps/files/3076.PDF.

At-Thabari. (1999). Jamii Bayan Fi Ta'wilil Quran. Beirut: Daarul Kitab.

Aziz, A. B. (2004). Nilai dan etika pengurusan: Analisa dari perspektif agama-agama di Malaysia. Seminar Nilai Dan Komuniti (SIVIC), 1-13.

Bakar, A. M. S., Long, A. S., \& Bakar, I. A. (2013). Perspektif Aristotle dan Al-Ghazali terhadap konsep Persahabatan. Jurnal Hadhari, 5(1), 21-36.

Braun, V., \& Clarke, V. (2006). Using thematic analysis in psychology. Qualitative Research in Psychology, 3, 77-101.

Bradley, R. L. (2013). Keeping it Secret: The morality of confidentiality. Retrieved Mei, 2,2021 from

https://www.academia.edu/4089284/Keeping_it_Secret_The_Morality_of_Confidenti ality

Eileen S., W., \& Westerlund, S. R. (1975). Humane Education: An Overview. United States: The National Association for The Advancement of Human Education.

Elvina, I. (2017). Nilai-nilai akhlak sosial dalam al-Quran. Kementerian Agama Universitas Islam negeri Walisongo Semarang fakultas ilmu tarbiyah dan keguruan.

Engelen, B., \& Nys, T. (2008). Tolerance: A Virtue? Towards a broad and descriptive definition of tolerance. Philosophy in the Contemporary World, 15(1), 44-54.

Caldwell, C. (2017). Understanding Kindness - A Moral Duty of Human Resource Leaders. The Journal of Values-Based Leadership, 10(2), 1-18.

Cicek, V., Ulker, R., \& Tarman, B. (2012). Comparison of character education in US and Turkish educational systems: Globalizing American education system. Energy Education Science and Technology Part B: Social and Educational Studies, 4(3), 1311-1322 
Como, J. M. (2007). Care and Caring: A look at History, Ethics, and Theory, 11(4), 37-45. Retrieved May 4, from

https://www.researchgate.net/publication/278964865_Care_and_Caring_A_Look_at_Histor Y_Ethics_andTheory

Creswell, J. W., \& Poth, C. N. (2017). Qualitative Inquiry and Research Design: Choosing Among Five Approaches. United States: SAGE Publications Inc.

Ferguson, T., \& Roofe, C. G. (2020). SDG 4 in higher education: challenges and opportunities. International Journal of Sustainability in Higher Education, 21(5), 959-975. https://doi.org/10.1108/IJSHE-12-2019-0353

Gill, S. S., Ramli, M. R., \& Talib, A. Tarmizi. (2015). Kesedaran Patriotik dalam kalangan belia bandar di semenanjung Malaysia. Jurnal Sosial IImu Politik Universitas Hasanuddin, 1(1), 111-120.

Godlewski, R. (2015). Definition of duty and freedom with conflict. Review of Contemporary Philosophy, 14, 102-125.

Hasanah, Z. R. (2016). Nilai-nilai pendidikan Karakter surah al-An'am ayat 151-153 dan penerapannya dalam PAI. Sarjana Pendidikan. Fakultas Tarbiyah dan Ilmu Keguruan Institut agama Islam Negeri Salatiga. Retrieved Aug 12, 2021 from http://erepository.perpus.iainsalatiga.ac.id/1318/

Hashim, M. I. A. M., \& Azhar, A. (2010). Prinsip dan Model Negara Islam: Definisi dan Aplikasinya di Malaysia. Journal of Covernance and Development, 6, 53-68.

Haydon, G. (2006). Respect for Persons and for Cultures as a basis for National and Global citizenship. Journal of Moral Education, 35(4), 457-471.

Hidayat D. T. K. (2020). Implementasi penanaman Nilai Sosial dalam membangun karakter siswa kelas $\mathrm{V}$ sekolah dasar melalui pembelajaran IPS. Tesis Magister Pendidikan. Universitas Negeri Semarang.

Ibnu Hisham. (1985). Mughniyu al-Labib an Kutubil a'Aarib. Tahkik: Muhammad Ali Hamdallah. Damsyik: Dar al-Fikr.

Ibnu Hisham. (1997). Sharh Qatr al-Nada wa Bal al-Sada. Tahkik: Muhd Khair Ta'mah Halbi. Lubnan: Dar al-Ma'rifah.

Ismail, N. S. A., Abdullah, N., Hassan, K., Samsudin, S., Zakuan, U. A. A., Yusof, R., \& Zaki, N. M. (2017). Kesejahteraan hidup warga emas: Perancangan berasaskan gender. GEOGRAFIA. Journal of Society and Space, 13(3). 75-85

Jomaa, A. A. (2018). Effectiveness of video in the teaching of the Prophet's biography in the curricula of Islamic education "Experimental Study". Basic Education College Magazine for Educational and Humanities Sciences, 37, 78-90.

Kafadar, T., Ozturk, C., \& Katilmis, A. (2018). Comparison of the Social Studies curricula of different countries in terms of values education. Kirsehir Education Faculty, 19(1), 178200. https://doi.org/10.29299/kefad.2018.19.005

Kasdi A. (2014). Pemikiran Ibnu Khaldun dalam Perspektif Sosiologi dan Filsafat Sejarah. Fikrah, 2(1), 291-307.

Katilmis, A. (2017). Values education as perceived by Social Studies teachers in objective and practice dimensions. Educational Sciences: Theory \& Practice, 17(4), 1231-1254. https://doi.org/10.12738/estp.2017.4.0570

Keown, P., Parker, L., \& Tiakiwai, S. (2005). Values in the New Zealand curriculum. New Zealand: Wilf Malcolm Institute of Educational Research 
Kertas Kerja Kajian Sistem Pendidikan Kebangsaan (MTT 2353). Retrieved April, 4, 2021 from https://www.scribd.com/doc/91202794/Kertas-Kerja-Kajian-Sistem-PendidikanKebangsaan

Khamis, A. M., Kamel, M. S., \& Salichs, M. A. (2006). Cooperation: Concepts and General Typology. IEEE International Conference. Retrieved May 5, from https://www.researchgate.net/publication/4262413_Cooperation_Concepts_and_Ge neral_Typology

Kinnier, R. T., Kernes, J. L., \& Dautheribes, T. M. (2000). A Short List of Universal Moral Values. Counselling and Values, 45(1), 4-16.

Mahadi, Z, \& Sino, H. (2007). Hubungan nilai masyarakat \& pembangunan: satu Analisa. MALIM: Jurnal Pengajian Umum Asia Tenggara, 8, 77-94.

Merey, Z., Kus, Z., \& Karatekin, K. (2012). Comparison of elementary Social Studies curricula of Turkey and the United States on values education. Educational Sciences: Theory \& Practice, 12(2), 1627-1632.

Merriam, S. B., \& Tisdell, E. J. (2016). Qualitative Research: A Guide to Design and Implementation. United States of America: Jossey Bass.

Mohamad, N., Yusoff, S. Z., Abdullah, N. H., Azmy, S. N. M. S. (2017). Pengajaran dan Pembelajaran Bahasa Arab: Tinjauan Awal Peringkat Sekolah Rendah Terengganu. Seminar Kebangsaan Bahasa dan Kesusasteraan Arab.

Mohamed, M. N., Yusof, M., Hamzah, R., \& Udin, A. (2011). Kemantapan Penghayatan Guru Terhadap Falsafah Pendidikan Kebangsaan Asas Membangunkan Guru Cemerlang. Journal of Edupres, 1(September), 271-278.

Musa, H., Said, N., Rodi, R. C., \& Karim, S. S. (2012). Hati Budi Melayu: Kajian keperibadian Sosial Melayu kearah penjanaan Melayu Gemilang. GEMA Online Journal of Language Studies, 12(1), 163-182.

Musling, M. N., Ismail, M. Z., Rahman, M. A. R. A., \& Amat, R. A. M. @. (2020). Universal Moral Values in Arabic Language Structure: A Concept, Component and Meaning. International Journal of Academic Research in Business and Social Sciences, 10(7), 852868.

Musling, M. N., \& Ismail, M. Z. (2021). Universal Social Moral Values in Shāhid of Quranic Syntax: Nominal and Verbal Sentences. International Journal of Academic Research in Business and Social Sciences, 11(12), 738-756.

Musling, M. N., Ismail, M. Z., Darmi, R., Kamaruddin, A. Y., \& Jaffar, M. N. (2022). Summary of possible universal moral values in language pedagogy: A systematic review. Journal of Language and Linguistic Studies, 18(1), 40-57.

Nirwana, D. (2008). Konsep Makkiyyah dan Madaniyah dalam Studi Hadith. Jurnal Islamica, $3(1)$.

Nurhayati. (2017). Konsep Pendidikan Islam dalam Qs Luqman 12-19. Jurnal Aqidah-Ta, 3(1), 48-58.

Octavia, L., Syatibi, L., Ali, M., Gunawan, R., \& Hilmi, A. (2014). Pendidikan Karakter berbasis Pesantren. Jakarta: Rene Books.

Omar, S. I., \& Mohamed, B. (2014). Amalan Hospitaliti dalam masyarakat Melayu tradisional dan sekarang: Kajian kes- Program Inap Desa di Jalan Bharu, Pulau Pinang. Retrieved May 4, from

https://www.researchgate.net/publication/277009390_Amalan_Hospitaliti_Dalam_Masyar akat_Melayu_Tradisional_Dan_Sekarang_Kajian_Kes_-

_Program_Inap_Desa_Di_Jalan_Bharu_Pulau_Pinang 
Osman, W. R. H. M., \& Wahab, H. A. (2018). Kesantunan Berbahasa Kaunselor pelatih dalam sesi kaunseling. GEMA Online Journal of Language Studies, 18(1), 252-269.

Population Reference Bureau. (2000). Conveying concerns: Women report on families in transition. Washington, DC: Author.

Rahman, A. A., Ahmad, A. R., Malek, J. A., \& Awang, M. M. (2016). Penglibatan sosial dan pembudayaan nilai murni melalui pembelajaran tidak formal dalam kalangan penduduk bandar Putrajaya. Kajian Malaysia, 34(2), 75-100.

Rajab, Z., Halim, Z. A., \& Teh, K. S. M. (2016). Shahid Al-Quran Dalam Karya Tatabahasa Arab: Satu Sorotan Literatur Secara Sistematik. Journal of Nusantara Studies (JONUS), 1(1), 18-33. https://doi.org/10.24200/jonus.vol1iss1pp18-33

Rajab, Z., Mustafa, M. Y., \& Jaafar, M. K. (2015). Pengajaran dan Pembelajaran Bahasa Arab berbantukan gaya Shahid al-Quran (GSQ). In Persidangan Kebangsaan Pendidikan Islam. Seremban: Institut Pendidikan Guru Kampus Pendidikan Islam, Bangi.

Rashid, A. R. A. (2001). Nilai-Nilai Murni Dalam Pendidikan: Menghadapi Perubahan Dan Cabaran Alaf Baru. Kuala Lumpur: Utusan Publications \& Distributors Sdn. Bhd.

Rozak, P. (2017). Indikator Tawadhu dalam Keseharian. Jurnal Madaniyah, 1(12), 174-187.

Saldana, J. (2011). Fundementals of Qualitative research. New York: Oxford University Press.

Shaharom, M. H. (2019). Menghormati orang lain. Sinar Harian. https://www.sinarharian.com.my/article/33059/KOLUMNIS/Menghormati-orang-lain

Sinar Harian. 06/09/2021. Apa Erti Setia? Retrieved May 4 from https://www.ukm.my/pkk/wpcontent/uploads/bsk-pdf-manager/060918APA_ERTI_SETIA-SINAR_1916.pdf

Ngaisah, S. (2018). Nilai-nilai pendidikan Akhlak dalam surah al-Hujurat ayat 11-13. Sarjana Pendidikan. Fakultas Tarbiyah dan Ilmu Keguruan Institut agama Islam Negeri Purwokerto. Retrieved Aug 12, 2021 from http://repository.iainpurwokerto.ac.id/4407/1/COVER_ABSTRAK_DAFTAR\%20ISI_BAB \%20I_BAB\%20V_DAFTAR\%20PUSTAKA.pdf

Zubaidah, S. (2016). Keterampilan abad ke-21: Keterampilan yang diajarkan melalui Pembelajaran. Seminar Nasional Pendidikan dengan tema "Isu-isu strategis pembelajaran MIPA abd 21. Kalimantan Barat.

Strauss, C., Taylor, L. B., Gu, J., Kuyken, W., Baer, R., Jones, F., \& Cavanagh, K. (2016). What is compassion and how can we measure it? A review of definitions and measures. Clinical Psychology Review, 47, 15-27. https://doi.org/10.1016/j.cpr.2016.05.004

Sutikno. (2013). Pola Pendidikan Islam dalam surah Luqman ayat 12-19. Jurnal Pendidikan Agama Islam, 2(2), 288-302.

Taku Ikemoto. (1996). Thesis Research: Moral Education in Japan; Implications for American Schools. Retrieved April, 26, 2021 from http://www.hiho.ne.jp/taku77/papers/thes595.htm

Treger, Stanislav., Sprecher, S., \& Hatfield, E. (2013). Love. In Book: Encyclopedia of Quality of Life Research. Retrieved May 4, from https://www.researchgate.net/publication/235246181_Love.

Umar, J. (2017). Peranan Nilai Sosial dalam Pengembangan Pendidikan Umum. Al-Idarah: Jurnal Kependidikan Islam. Retrieved May 5, 2021, from https://media.neliti.com/media/publications/58108-ID-peranan-nilai-sosial-dalampengembangan.pdf 
Ummah, U. R. (2017). Nilai-nilai Pendidikan akhlak dalam surah al-Furqan ayat 63-67. Sarjana Pendidikan (SI). Fakultas Tarbiyah dan IImu Keguruan Institut agama Islam Negeri Salatiga. Retrieved Aug 12, 2021 from https://digilib.uin-suka.ac.id/id/eprint/26291/

World Health Organization. (1999). Men Ageing and Health, Achieving health across the life span. Geneva.

Yaakob, Z. A., \& Moris, Z. (2019). Merangka semula Falsafah Keamanan Sejagat dalam konteks Malaysia. ISLAMIYYAT, 41(1), 69-81.

Yusof, N. M. (2010). Perspektif Sosiologi dalam fungsi Sosial pendidikan di Malaysia. DP, 10(1), 3749.

Zakaria, A. R., \& Salleh, N. M. (2011). Konteks keluarga dan hubungannya dengan penglibatan Ibu-bapa dalam pendidikan anak-anak di sekolah menengah. Jurnal Pendidikan Malaysia, 36(1). 35-44.

Zbar, M. V., Brown, M. D., Bereznicki, M. B., \& Hooper, D. C. (2003). Values Education Study. In Curriculum Corporation. Retrieved May 4, 2021 from http://www.dest.gov.au/NR/rdonlyres/F6BA105C-4167448B-89A337769A624AF8/4528/VES_Report.pdf

Zunker, V. G. (2006). Career Counseling. A Hollistic Approach. Belmont: Thomson Brooks/Cole. 